\title{
Effects of dietary mineral acids on voluntary food intake, digestion, mineral metabolism and acid-base balance of sheep
}

\author{
BY J. L. L'ESTRANGE AND F. MURPHY \\ Department of Agricultural Chemistry and Soil Science, Faculty of \\ Agriculture, University College Dublin, Glasnevin, Dublin 9, \\ Republic of Ireland
}

(Received 25 March 1971 - Accepted 10 Jamuary 1972)

I. A pelleted grass meal diet alone (control) or supplemented with hydrochloric acid, sulphuric acid or a $\mathrm{I}: \mathrm{I}$ mixture of these acids, at 320 mequiv. $/ \mathrm{kg}$, was offered ad lib. to eight sheep in a double $4 \times 4$ Latin square design for $20 \mathrm{~d}$.

2. The $\mathrm{HCl}$ and $\mathrm{HCl}-\mathrm{H}_{2} \mathrm{SO}_{4}$ treatments each reduced food intake of the sheep by $19 \%$ and the $\mathrm{H}_{2} \mathrm{SO}_{4}$ treatment reduced it by $30 \%$. Average daily intake of acid was 397,333 and 299 mequiv. on the $\mathrm{HCl}, \mathrm{HCl}-\mathrm{H}_{2} \mathrm{SO}_{4}$ and $\mathrm{H}_{2} \mathrm{SO}_{4}$ treatments respectively.

3. Rumen fluid $\mathrm{pH}$ was decreased by each acid treatment by $0.1-0.2$ units without any appreciable changes in total or individual volatile fatty-acid concentrations. Ory-matter digestibility was slightly increased by each acid treatment.

4. Blood $\mathrm{pH}$, plasma bicarbonate and blood base excess were decreased by each acid treatment; sulphate concentration in serum was increased by the $\mathrm{HCl}-\mathrm{H}_{2} \mathrm{SO}_{4}$ and $\mathrm{H}_{2} \mathrm{SO}_{4}$ treatments.

5. In urine the acid treatments decreased the $\mathrm{pH}$ from a control value of $8 \cdot 0$ to approximately $6 \cdot 0$; associated with this was a large decrease in urinary bicarbonate and a large increase in urinary ammonia-nitrogen and calcium excretions.

6. The chloride and sulphur contributed by the acid treatments were almost entirely absorbed and excreted in the urine. Fach acid treatment caused a negative balance of Ca equal to the increase in urinary $\mathrm{Ca}$. Effects on other minerals were small.

7. The effect of the $\mathrm{HCl}$ and the $\mathrm{HCl}-\mathrm{H}_{2} \mathrm{SO}_{4}$ treatments on voluntary food intake is ascribed to metabolic acidosis and of the $\mathrm{H}_{2} \mathrm{SO}_{4}$ treatment to excess dietary sulphate-S.

Virtanen (1933) formulated a method of fodder preservation as silage by direct acidification with mineral acids which became popularly known as the A.I.V. method. Virtanen (r933) claimed that silage preserved with sulphuric acid alone was much less palatable for cows than silage preserved with a mixture of hydrochloric and sulphuric acids. He suggested that the effect of the sulphuric acid was possibly due to an interference with cellulose digestion by the animals. More recently, ammonium bisulphate and sodium bisulphate have been used as silage additives on the same principle of directly lowering the $\mathrm{pH}$ of the grass ensiled. When added at a level of $7^{\cdot 14} \mathrm{~g} / \mathrm{kg}$ of fresh herbage, ammonium bisulphate gave good silage preservation (McCarrick, 1962, 1964); however, the voluntary intake by cattle of the silage was found to be much lower than that of silage preserved with molasses (e.g. Clifford, I963; Bryan, I964; McCarrick, Keane \& Tobin, I965). The last two authors ascribed the reduced silage intake to excess dietary sulphate-sulphur contributed by the salt. McCarrick, Poole \& Maguire ( 1965$)$, on the other hand, ascribed the reduction in silage intake to metabolic aridosis induced by the salt.

In a previous experiment, to clarify this problem, the effects of various sulphate salts and sulphuric acid supplements on the voluntary intake of a pelleted grass-meal 
Table I. Chemical composition ( $g / 100 \mathrm{~g}$ dry matter) of the pelleted grass meal given as the basal diet

\begin{tabular}{lrll}
\multicolumn{1}{c}{ Proximate analysis } & \multicolumn{2}{c}{ Mineral content } \\
Crude protein & $16 \cdot 8$ & Potassium & $2 \cdot 50$ \\
Ether extract & $4 \cdot 2$ & Sodium & $0 \cdot 28$ \\
Crude fibre & $\mathbf{2 2} \cdot 0$ & Calcium & $0 \cdot 73$ \\
Ash & $9 \cdot 6$ & Magnesium & $0 \cdot 20$ \\
Nitrogen-free extractives & $47 \cdot 4$ & Chloride & $1 \cdot 26$ \\
& & Phosphorus & $0 \cdot 26$ \\
& & Sulphur & $0 \cdot 45$
\end{tabular}

diet by sheep were compared (L'Estrange, Clarke \& McAleese, r969). In that experiment it was observed that sodium sulphate, added to the diet to provide $\mathrm{I} g \mathrm{~S} / \mathrm{roo} \mathrm{g}$ dry matter (DM), decreased food intake by $22 \%$, whereas ammonium bisulphate, ammonium sulphate or sulphuric acid also added at $\mathrm{x} g \mathrm{~S} / \mathrm{I}$ oo g DM, each decreased food intake by approximately $44 \%$. The effect of sodium sulphate was ascribed to dietary sulphate-S, whereas the increased effect of the other compounds was ascribed to metabolic acidosis, which each induced to the same degree. Because only sulphate compounds were used in that experiment it was not possible to separate completely the effects due to metabolic acidosis and to dietary sulphate.

In this paper these aspects are further examined by comparing the effects of dietary hydrochloric and sulphuric acids, added to a pelleted grass-meal diet, on food intake and metabolism of sheep. Alongside acid-base and mineral metabolism, other factors were studied which might be influenced by the treatments and which have been demonstrated to affect voluntary food intake of ruminants, such as rumen fluid $\mathrm{pH}$ (Bhattacharya \& Warner, r967), rumen fluid acetate concentration (Baile, I968) and DM digestibility (Blaxter $\&$ Wilson, I 962 ).

A preliminary report of the work has already been presented (L'Estrange \& Murphy, 1971).

\section{EXPERIMENTAL}

Animals

The sheep used were 2-year-old Cheviot wethers (castrated males) and they were housed in metabolism cages throughout the experiment.

\section{Treatments}

Pelleted, dried-grass meal, similar in composition (Table $I$ ) to that of good-quality grass for ensilage, was used as the basal diet. The grass-meal pellets were supplemented with either hydrochloric acid or sulphuric acid or a mixture (I:I) of the two acids $\left(\mathrm{HCl}-\mathrm{H}_{2} \mathrm{SO}_{4}\right)$ at a level of 320 mequiv. $/ \mathrm{kg}$. This amount of acid reduced the $\mathrm{pH}$ of a mixture of grass pellets and distilled water $(i: 5)$ to $3 \cdot 8$, and so was chosen as being a desirable level for the proper preservation of silage. Batches of the experimental diets were prepared by pouring $200 \mathrm{ml}$ of acid solution on to $2 \mathrm{~kg}$ of the grass pellets in a plastic container which was shaken thoroughly to ensure an even mixture. For the control, the grass-meal pellets were diluted with distilled water to the same extent. 
The diets were then stored in plastic bags and each batch was used within $3 \mathrm{~d}$ of being prepared.

The four diets, i.e. control, $\mathrm{HCl}, \mathrm{HCl}-\mathrm{H}_{2} \mathrm{SO}_{4}$ and $\mathrm{H}_{2} \mathrm{SO}_{4}$, were given to eight sheep according to two balanced $4 \times 4$ Latin squares in a change-over design. In block $\mathrm{A}$ the four sheep were non-fistulated and all the blood samples, urine and faeces collections were taken from these animals; in block $B$ the four sheep were fitted with permanent rumen cannulas and all the rumen fluid samples were taken from them.

\section{Feeding}

The experimental diets were offered ad lib. for $20 \mathrm{~d}$ to the sheep in both blocks. The sheep in block $A$ then had an $8 \mathrm{~d}$ recovery period on the control diet ad lib. before going on to their next treatment. The sheep in block B, after the $20 \mathrm{~d}$ ad lib. period, continued on their diet at a restricted level of $\mathrm{I} \mathrm{kg} / \mathrm{d}$, offered once daily at 10.00 hours for a further $5 \mathrm{~d}$, which enabled rumen-fluid studies to be made when DM intake was the same on each treatment. This period was followed by a recovery period of $3 \mathrm{~d}$ on the control diet $a d$ lib. before the sheep went on to their next treatment. During ad lib. feeding, each animal was offered approximately $500 \mathrm{~g}$ in excess of its intake on the previous day. Food residues were removed every and day and dried. Distilled water was provided throughout and its intake recorded.

\section{Urine and faeces collections}

Urine was collected in conical flasks containing a layer of toluene and its volume and $\mathrm{pH}$ were recorded daily. Two subsamples of each collection were taken; the one for bicarbonate determination was stored under a layer of toluene and the other, for determination of ammonia-nitrogen and minerals, was acidified with glacial acetic acid and stored under a layer of toluene. Faeces were collected in plastic buckets and their wet weight was recorded every $2 \mathrm{~d}$. A sample of each $2 \mathrm{~d}$ collection was dried immediately. Composite samples of both urine and faeces were bulked for days $I-2,3-4$, $5^{-6,7-8,9-20}$ on the treatments and for days $1-2,3^{-4}, 5^{-6}$ and $7^{-8}$ during the recovery period.

\section{Blood and rumen fluid sampling}

Blood samples were taken from the jugular vein of the sheep in block A at I I.30 hours on days $0,2,4,6,10,17,21,23$ and 25 . One sample for determination of blood $\mathrm{pH}$ and plasma total carbon dioxide was collected under a layer of liquid paraffin into a small heparinized McCartney bottle. The $\mathrm{pH}$ was recorded immediately and then the sample was centrifuged and the plasma transferred to another bottle containing liquid paraffin before total $\mathrm{CO}_{2}$ was measured. A second sample was allowed to clot for $24 \mathrm{~h}$ and then centrifuged; the serum was withdrawn and stored at $-5^{\circ}$ for mineral determinations.

Rumen fluid samples were taken from the fistulated sheep in block B, using an Edward's vacuum pump. Samples were taken on days $\mathrm{I}_{5}$ and $\mathrm{I} 7 \mathrm{of}$ the ad lib. period, at $08.00,12.00,16.00$ and 20.00 hours. Samples were also taken on the last $2 \mathrm{~d}$ of the $5 \mathrm{~d}$ period of restricted intake at $\mathrm{I} h$ before feeding and at 2,4 and $6 \mathrm{~h}$ after feeding. The $\mathrm{pH}$ of whole rumen contents was measured immediately after sampling. 


\section{Analytical methods}

The DM content of the diets, food residues and faeces were determined by drying to constant weight at $100^{\circ}$. The $\mathrm{pH}$ values of urine and rumen fluid were recorded with a Radiometer pH meter (type pH M 26: Radiometer A/S, 72 Emdrupvej, Copenhagen NV, Denmark) using a glass electrode. The $\mathrm{pH}$ values of blood were recorded with the same Radiometer $\mathrm{pH}$ meter, using a microelectrode unit (type E. 502I) and a watercirculation thermostat (type VTS ${ }_{13}$ ) at $38^{\circ}$. Total $\mathrm{CO}_{2}$ concentrations in plasma and urine and ammonia- $\mathrm{N}$ in urine were determined by the method of Conway (1962). $P_{\mathrm{CO}_{2}}$ and base excess (BE) of blood were calculated from blood $\mathrm{pH}$ and plasma $\mathrm{CO}_{2}$ values according to Davenport (1969). The $\mathrm{BE}$ value is the amount of titratable base in blood titrated to $\mathrm{pH} 7.40$ at a $P_{\mathrm{CO}_{2}}$ of $40 \mathrm{~mm} \mathrm{Hg}$ and at $37^{\circ}$. A zero value for $\mathrm{BE}$ in the sheep was chosen as that equivalent to $26 \mathrm{mmol} \mathrm{HCO}_{3}^{-} / 1$ (Billitzer \& Jarrett, 1970). In serum, urine, ashed faeces and food samples, calcium and magnesium were determined by atomic absorption spectroscopy, and $\mathrm{Na}$ and potassium by flame photometry. Total phosphorus was cstimated in ashed urine, faeces and food and in serum by the method of Fiske \& Subbarow (1925). Sulphate-S in serum was detcrmined by the method of Dean ( 1966 ), total-S in urine, faeces and food by the method of Shaw (1959), Cl in urine and in deproteinized serum by the method of Conway ( 1962$), \mathrm{Cl}$ in faeces and food by the method of the Association of Official Agricultural Chemists ( 1965$)$, and volatile fatty acids (VFA) in strained rumen fluid by gas-liquid chromatography by the method of Baumgardt (I964).

\section{RESULT S}

The eight sheep remained healthy throughout the experiment and increased in mean weight from $4 \mathrm{I}$ to $47 \mathrm{~kg}$ during the 4 -month period of the experiment. The weight gain of the sheep was significantly affected by treatments, being highest on the control and lowest on the $\mathrm{H}_{2} \mathrm{SO}_{4}$ treatment (Table 2).

\section{DM intake}

DM intake (Table 2) was significantly reduced by each of the acid treatments. The effect was greatest with the $\mathrm{H}_{2} \mathrm{SO}_{4}$ treatment, which reduced intake over the $20 \mathrm{~d}$ period to $70 \%$ of the control; the $\mathrm{HCl}$ and the $\mathrm{HCl}-\mathrm{H}_{2} \mathrm{SO}_{4}$ treatments each reduced intake to $8 \mathrm{I} \%$ of the control. On the control diet, DM intake was constant for the first $6 \mathrm{~d}$ at about $\mathrm{I} \cdot 35 \mathrm{~kg} / \mathrm{d}$ and then it increased gradually during the last $14 \mathrm{~d}$ to about I. $55 \mathrm{~kg} / \mathrm{d}$ (Fig. I). The patterns of intake on the $\mathrm{HCl}$ and on the $\mathrm{HCl}-\mathrm{H}_{2} \mathrm{SO}_{4}$ treatments were almost identical. Intake on each was slightly below the control on the ist day and then gradually decreased to its lowest level of about $\mathrm{I} \mathrm{kg}$ on day 4. It then gradually increased over the remaining $16 \mathrm{~d}$, as did intake of the control diet, so that the reduction in intake relative to the control remained at about $0.3 \mathrm{~kg} / \mathrm{d}$. Intake on the $\mathrm{H}_{2} \mathrm{SO}_{4}$ treatment was slightly reduced on the ist day of treatment and then decreased to its lowest level of $0.72 \mathrm{~kg}$ on day 4 . It gradually increased over the remaining $\mathrm{I} 6 \mathrm{~d}$ at a rate slightly higher than with the other treatments so that the difference between them was somewhat less at the end of the $20 \mathrm{~d}$ period. 
Table 2. Live-weight change, dry-matter (DM) intake, water intake, water excretion and DM digestibility for eight sheep given pelleted grass meal alone or supplemented with mineral acids

\begin{tabular}{|c|c|c|c|c|c|c|}
\hline & $\begin{array}{l}\text { Control } \\
\text { (grass } \\
\text { meal } \\
\text { alone) }\end{array}$ & $\begin{array}{c}\text { Grass } \\
\text { meal + } \\
\text { HCl }\end{array}$ & $\begin{array}{c}\text { Grass } \\
\text { meal }+ \\
\left(\mathrm{HCl}-\mathrm{H}_{2} \mathrm{SO}_{4}\right)\end{array}$ & $\begin{array}{c}\text { Grass } \\
\text { meal }+ \\
\mathrm{H}_{2} \mathrm{SO}_{4}\end{array}$ & $\begin{array}{l}\text { SE of } \\
\text { treatment } \\
\text { mean }\end{array}$ & $F$ test $\dagger$ \\
\hline Live-wt change $(\mathrm{g} / \mathrm{d})+($ days $0-20)$ & $168^{a}$ & $82^{\mathrm{ab}}$ & $54^{\mathrm{b}}$ & $22^{\mathrm{b}}$ & 34 & * \\
\hline $\begin{array}{l}\text { DM intake }(\mathrm{kg} / \mathrm{d})_{+} \\
\text {Days o-zo } \\
8 \mathrm{~d} \text { recovery period for block } \mathrm{A} \\
3 \mathrm{~d} \text { recovery period for block } \mathrm{B}\end{array}$ & $\begin{array}{l}I \cdot 46^{a} \\
I \cdot 4 I \\
I \cdot 54\end{array}$ & $\begin{array}{l}I \cdot 18^{b} \\
I \cdot 39 \\
I \cdot 48\end{array}$ & $\begin{array}{l}I \cdot I 8^{b} \\
I \cdot 26 \\
I \cdot 56\end{array}$ & $\begin{array}{l}I \cdot O 2^{C} \\
I \cdot 35 \\
I \cdot 5 \circ\end{array}$ & $\begin{array}{l}0.033 \\
0.053 \\
0.040\end{array}$ & $\begin{array}{l}* * \\
\text { NS } \\
\text { NS }\end{array}$ \\
\hline $\begin{array}{l}\text { Water intake (days } 0-20 \text { ) } \ddagger \\
1 / \mathrm{d} \\
1 / \mathrm{kg} \text { DM eaten }\end{array}$ & $\begin{array}{l}4 \cdot 06^{\mathrm{a}} \\
2 \cdot 77\end{array}$ & $\begin{array}{l}3 \cdot 46^{b} \\
2 \cdot 94\end{array}$ & $\begin{array}{l}3 \cdot 37^{\mathrm{b}} \\
2 \cdot 83\end{array}$ & $\begin{array}{l}2 \cdot 73^{\mathrm{c}} \\
2 \cdot 69\end{array}$ & $\begin{array}{l}0.11 \\
0.07\end{array}$ & NS \\
\hline $\begin{array}{l}\text { Urine volume (days o-20) } \$ \\
\mathrm{I} / \mathrm{d} \\
1 / \mathrm{kg} \text { DM eaten }\end{array}$ & $\begin{array}{l}1 \cdot 39 \\
1 \cdot 05^{\mathrm{c}}\end{array}$ & $\begin{array}{l}1 \cdot 80 \\
r \cdot 64^{\mathrm{a}}\end{array}$ & $\begin{array}{l}I \cdot 48 \\
I \cdot 45^{\text {ab }}\end{array}$ & $\begin{array}{l}I-16 \\
I \cdot 26^{b c}\end{array}$ & $\begin{array}{l}0.14 \\
0.07\end{array}$ & $\begin{array}{l}\text { NS } \\
* *\end{array}$ \\
\hline $\begin{array}{l}\left.\% \mathrm{H}_{2} \mathrm{O} \text { in fueces (days } 0-20\right) \S \\
\text { DM digestibility } \S\end{array}$ & $69: 4$ & 644 & $64{ }^{\circ}$ & $68 \cdot 1$ & $\mathrm{I} \cdot 8_{4}$ & NS \\
\hline $\begin{array}{l}\text { Days } 0-8 \\
\text { Days } 8-20\end{array}$ & $\begin{array}{l}54^{-5} \\
54.5^{\mathrm{a}}\end{array}$ & $\begin{array}{l}56 \cdot 0 \\
56 \cdot 0^{b}\end{array}$ & $\begin{array}{l}55 \cdot 6 \\
56 \cdot 0^{b}\end{array}$ & $\begin{array}{l}53 \cdot 3 \\
58 \cdot 2^{c}\end{array}$ & $\begin{array}{l}0.8 \mathrm{I} \\
0.4 \mathrm{I}\end{array}$ & $\underset{* *}{N S}$ \\
\hline
\end{tabular}

$\uparrow$ Where the $F$ test shows a significant treatment effect the means are significantly different from each other $(P<0.05)$ if they do not have a letter in common. Significance levels: NS, $P>0.05$; *0.05 >P>0.01; **0.01 >P>0.001.

\pm Mean for eight sheep/treatment.

$\S$ Mean for four sheep/treatment.

DM intake during the recovery period showed no significant carry-over treatment effects (Table 2 and Fig. I).

\section{Water intake and excretion}

Daily water intake (Table 2) was significantly lower on each of the acid treatments than on the control. Water intake per unit of food eaten was not significantly affected by treatment, though it was higher on the $\mathrm{HCl}$ and the $\mathrm{HCl}-\mathrm{H}_{2} \mathrm{SO}_{4}$ treatments and lower on the $\mathrm{H}_{2} \mathrm{SO}_{4}$ treatment than on the control. There was no significant treatment effect on the volume of urine excreted or on the moisture content of the faeces. The volume of urine excreted per $\mathrm{kg}$ food eaten was, however, significantly higher on both the $\mathrm{HCl}$ and the $\mathrm{HCl}-\mathrm{H}_{2} \mathrm{SO}_{4}$ treatments than on the control.

\section{$D M$ digestibility}

The apparent digestibility of DM was significantly higher on each of the acid treatments for the second period (days 8-20) but not for the first period ('Table 2). This higher digestibility, which showed that the acid supplements did not adversely affect digestion of the grass meal, was probably due to the reduction in DM intake during the acid treatments.

\section{$p H$ and VFA in rumen fluid}

During $a d l i b$. feeding the mean $\mathrm{pH}$ of rumen fluid during the day was slightly lower on each acid treatment than on the control (Table 3 ) though only the value on the $\mathrm{HCl}$ treatment was significantly so $\left(P<0.0_{5}\right)$. On each treatment the highest $\mathrm{pH}$ values 


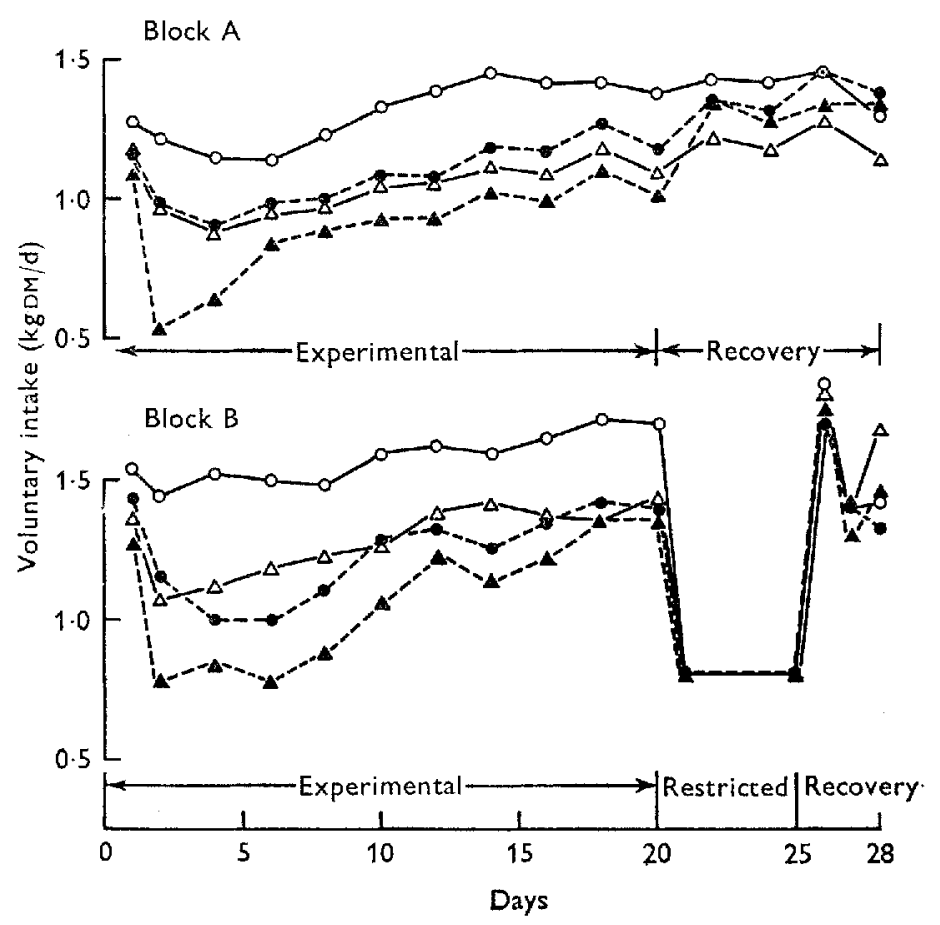

Fig. 1. Dry-matter (DM) intake by the sheep given grass-meal pellets alone ( $O$ ), or supplemented (320 mequiv. (kg food) with $\mathrm{HCl}(O), \mathrm{HCl}-\mathrm{H}_{2} \mathrm{SO}_{4}(\triangle)$ or $\mathrm{H}_{2} \mathrm{SO}_{4}(\Delta)$. In block A the diets were given $a d$ lib. for $20 \mathrm{~d}$ followed by an $8 \mathrm{~d}$ recovery period on the grass-meal peilets alone. In block B the diets were given $a d$ lib. for $20 \mathrm{~d}$ followed by a $5 \mathrm{~d}$ restricted period and by a $3 \mathrm{~d}$ recovery period on the grass-meal pellets alone. Values in each block are the means for four sheep/treatment.

were at 08.00 hours and the lowest at 16.00 hours (Fig. 2). The difference between the values for the acid treatments and the control was greatest at 12.00 hours, though the time of sampling by treatment interaction was not significant. This pattern was clearly related to the fact that the food was changed daily at 10.00 hours and some was immediately consumed.

During restricted feeding the mean $\mathrm{pH}$ of rumen fluid for the four sampling times during the day was significantly lower on each acid treatment than on the control $(P<0.05)$, though the difference was less than 0.2 units ('Table 3$)$. On each treatment values were highest $\mathrm{I} h$ before feeding and lowest $2 \mathrm{~h}$ after feeding (Fig. 2). The food was always eaten within $2 \mathrm{~h}$ of being offered. The difference between the values on the acid treatment and on the control was greatest at 2 and $4 \mathrm{~h}$ after feeding though the time of sampling by treatment interaction was not significant $(P \geqslant 0.05)$.

There was no significant treatment effect on total VFA concentration in rumen fluid during either ad lib. or restricted feeding. During ad lib. feeding total VFA concentration on each treatment was lowest at 08.00 hours and increased during the day to a peak at 20.00 hours (Fig. 2). During restricted feeding the values were lowest $\mathrm{I} \mathrm{h}$ before feeding, and highest at $2-4 \mathrm{~h}$ after feeding. The time of sampling by treatment interaction was not significant $(P \geqslant 0.05)$. 
Table 3. Effects of the treatments on the $p H$ and volatile fatty acid $(V F A)$ contents in rumen fluid of four sheep given grass meal, alone or supplemented with mineral acids

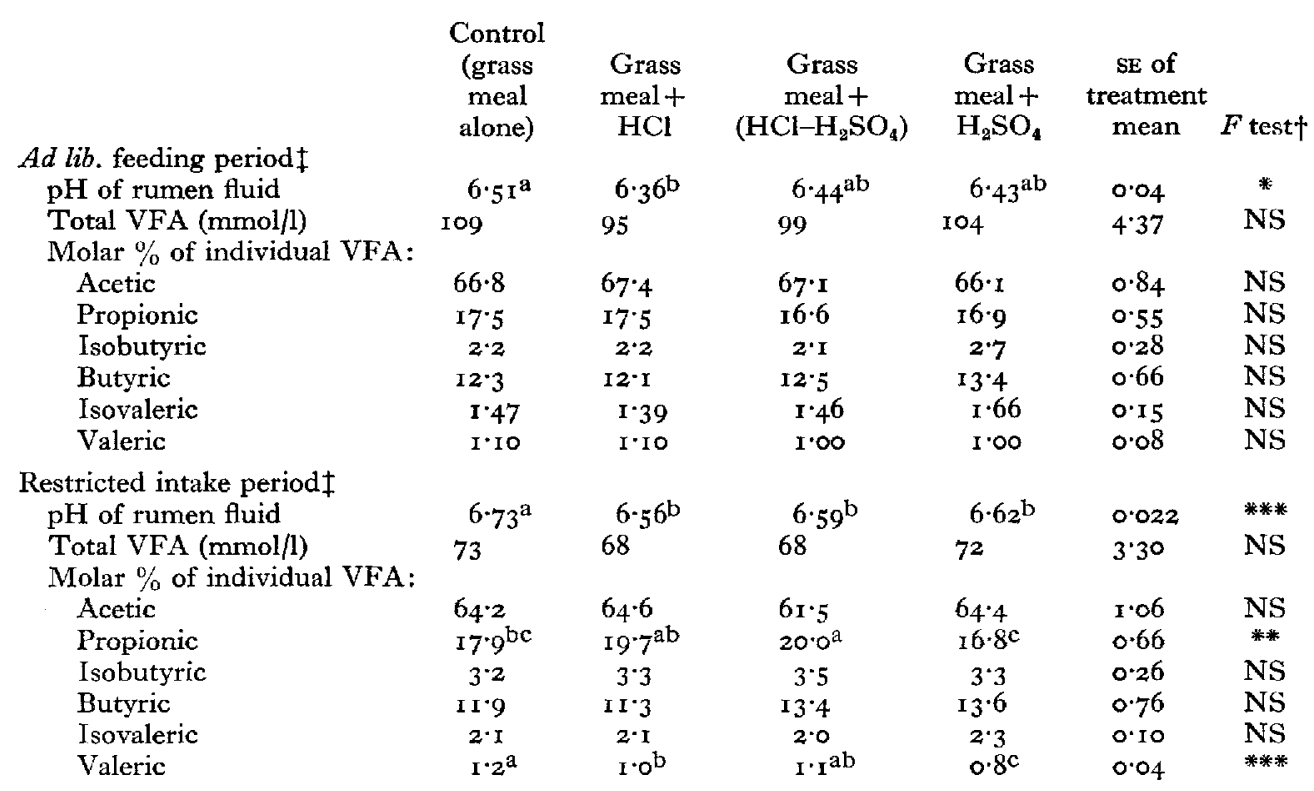

† Where the $F$ test shows a significant treatment effect the means are significantly different from each other $(P<0.05)$ if they do not have a letter in common. Significance levels: NS, $P>0.05$; *0.05 >P>0.01; **0.01 $>P>0.001$; **** $P<0.001$.

\$ Values for the ad lib. feeding period are the means for samples taken at $08.00,12.00,16.00$ and 20.00 hours on days 15 and 17 from four sheep/treatment. Values for the restricted intake period are the means for samples taken at $\mathrm{I} h$ before feeding and at 2,4 and $6 \mathrm{~h}$ after feeding on the last 2 days from four sheep/treatment.

During ad lib. feeding there was no significant treatment effect on the molar percentage of the individual VFA (Table 3). During restricted feeding there was a significant treatment effect $(P<0.0 \mathrm{I})$ on the molar percentage of propionic acid, the value being highest on the $\mathrm{HCl}$ and $\mathrm{HCl}-\mathrm{H}_{2} \mathrm{SO}_{4}$ treatments and lowest on the $\mathrm{H}_{2} \mathrm{SO}_{4}$ treatment. Although significant, the extent of the differences was small and was not associated with a significant treatment effect on the molar percentages of the other VFA cxcept for valeric acid. The molar percentage of the individual VFA was little affected by time of sampling during either ad lib. or restricted feeding and the time of sampling by treatment interactions on individual VFA values were also not significant.

\section{Blood acid-base status}

Each acid treatment caused a degree of metabolic acidosis in the sheep as indicated by blood $\mathrm{pH}$, blood $\mathrm{BE}$ and plasma $\mathrm{CO}_{2}$ values (Fig. 3). The $P_{\mathrm{CO}_{2}}$ values were not affected by treatment, mean values for days $2-\mathrm{I} 7$ on the control, $\mathrm{HCl}, \mathrm{HCl}-\mathrm{H}_{2} \mathrm{SO}_{4}$ and $\mathrm{H}_{2} \mathrm{SO}_{4}$ treatments being $37,38,37$ and $37 \mathrm{~mm} \mathrm{Hg}$ respectively.

The decrease in blood $\mathrm{pH}$, which was never greater than O.I 5 units, was gradual up to day 4. Plasma $\mathrm{CO}_{2}$ on the $\mathrm{HCl}$ and $\mathrm{HCl}-\mathrm{H}_{2} \mathrm{SO}_{4}$ treatments decreased within $2 \mathrm{~d}$ to 22 and $21 \mathrm{mmol} / \mathrm{l}$ respectively, remained at around these levels for some days and 

(a) Ad lib. feeding
(b) Restricted feeding
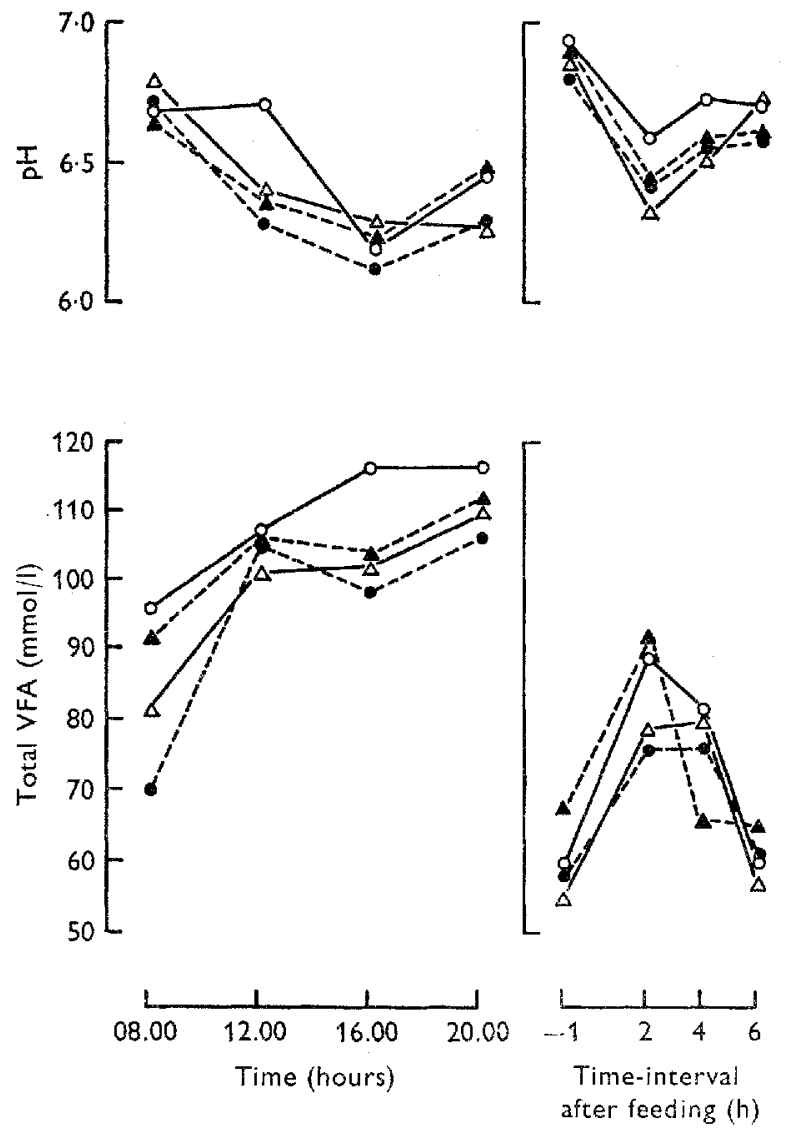

Fig. 2. $\mathrm{pH}$ and total volatile fatty acids (VFA) concentration of rumen liquor samples from sheep on control (O), $\mathrm{HCl}(\bullet), \mathrm{HCl}-\mathrm{H}_{2} \mathrm{SO}_{4}(\triangle)$ and $\mathrm{H}_{2} \mathrm{SO}_{4}(\Delta)$ treatments. The values are the means for samples from the four sheep in block B; (a) for days 15 and $\mathrm{I} 7$ during ad lib. feeding, $(b)$ for days 24 and 25 during restricted feeding. Other details as in Fig. $\mathbf{x}$.

increased slightly towards the end of the $20 \mathrm{~d}$ period. Plasma $\mathrm{CO}_{2}$ on the $\mathrm{H}_{2} \mathrm{SO}_{4}$ treatment decreased more gradually up to day Io. The values for blood BE showed a trend similar to that of plasma $\mathrm{CO}_{2}$, the lowest value being $-6 \mathrm{mmol} / \mathrm{l}$. The degree of metabolic acidosis on the $\mathrm{HCl}$ and $\mathrm{HCl}-\mathrm{H}_{2} \mathrm{SO}_{4}$ treatments was clearly greater for the first $6 \mathrm{~d}$ of treatment than subsequently. On the $\mathrm{H}_{2} \mathrm{SO}_{4}$ treatment the acidosis developed more towards the end of the $20 \mathrm{~d}$ period.

During the recovery period the blood $\mathrm{pH}$ increased to the levels on the control diet within $\mathrm{I} d$ of withdrawal of the supplements; plasma $\mathrm{CO}_{2}$ and blood $\mathrm{BE}$ both increased to slightly higher values than the values on the control diet.

\section{Minerals in serum}

The mean concentration of sulphate-S in the serum of the sheep was significantly higher on the $\mathrm{H}_{2} \mathrm{SO}_{4}$ treatment than on the $\mathrm{HCl}-\mathrm{H}_{2} \mathrm{SO}_{4}$ treatment, which in turn was significantly higher than on the $\mathrm{HCl}$ or control treatment (Table 4). Serum sulphate-S 

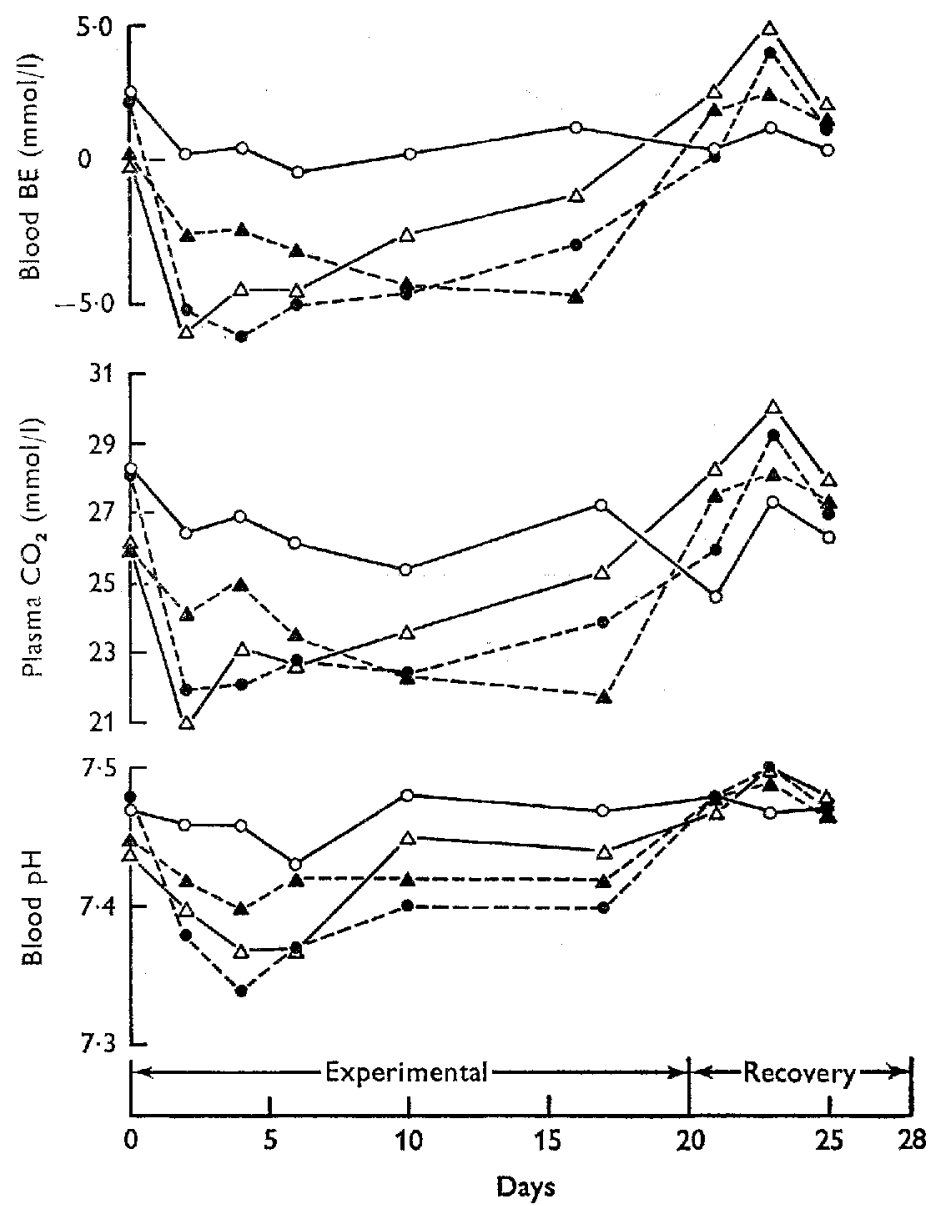

Fig. 3. Mean blood $\mathrm{pH}$, plasma total $\mathrm{CO}_{2}$ and blood base excess (BE) values for the four sheep in block $\mathrm{A}$ throughout the experiment on the treatments: control $(\mathrm{O}), \mathrm{HCl}\left(\mathrm{HCl}-\mathrm{H}_{2} \mathrm{SO}_{4}\right.$ $(\triangle)$ and $\mathrm{H}_{2} \mathrm{SO}_{4}(\Delta)$. Other details as in Fig. I.

Table 4. Effects of the treatments on the concentration of minerals $(\mathrm{mg} / \mathrm{I} 00 \mathrm{ml})$ in serum of sheep given grass meal alone or supplemenied with mineral acids

(Means for five samples talken from day 2 to day 17 from four sheep/treatment)

\begin{tabular}{|c|c|c|c|c|c|c|}
\hline & $\begin{array}{l}\text { Control } \\
\text { (grass } \\
\text { meal } \\
\text { alone) }\end{array}$ & $\begin{array}{c}\text { Grass } \\
\text { meal + } \\
\text { HCl }\end{array}$ & $\begin{array}{c}\text { Grass } \\
\text { meal }+ \\
\left(\mathrm{HC} 1-\mathrm{H}_{2} \mathrm{SO}_{4}\right)\end{array}$ & $\begin{array}{l}\text { Grass } \\
\text { meal }+ \\
\mathrm{H}_{2} \mathrm{SO}_{4}\end{array}$ & $\begin{array}{c}\text { se of } \\
\text { treatment } \\
\text { mean }\end{array}$ & $F$ test \\
\hline Sodium & $330 \cdot 0$ & $324 \cdot 2$ & $318 \cdot 8$ & 333.4 & $7 \cdot 59$ & NS \\
\hline Potassium & $22 \cdot 6$ & $22 \cdot 7$ & $2 \pi \cdot 6$ & $22 \cdot 3$ & 0.50 & NS \\
\hline Calcium & $7 \cdot 80$ & $7 \cdot 65$ & $7 \cdot 75$ & $7 \cdot 77$ & 0.70 & NS \\
\hline Magnesium & $\mathrm{I} \cdot 97$ & $I \cdot 85$ & $2 \cdot 06$ & 1.82 & O.II & NS \\
\hline Inorganic phosphate & $6 \cdot 82$ & $6 \cdot 75$ & $6 \cdot 49$ & $6 \cdot 6 \mathrm{I}$ & $0.6 \mathbf{I}$ & $\mathrm{NS}$ \\
\hline Chloride & 372 & $3^{88}$ & 394 & 386 & $5 \cdot 0$ & NS \\
\hline Sulphate-S & $6 \cdot 52^{a}$ & $6 \cdot 84^{a}$ & $7 \cdot 5^{\mathrm{b}}$ & $8 \cdot 22^{c}$ & 0.21 & $* *$ \\
\hline
\end{tabular}

$\uparrow$ Where the $F$ test shows a significant treatment effect the means are significantly different from each other $(P<0.05)$ if they do not have a letter in common. NS, $P>0.05$; *.0.017 $>P>0.00$ I. 


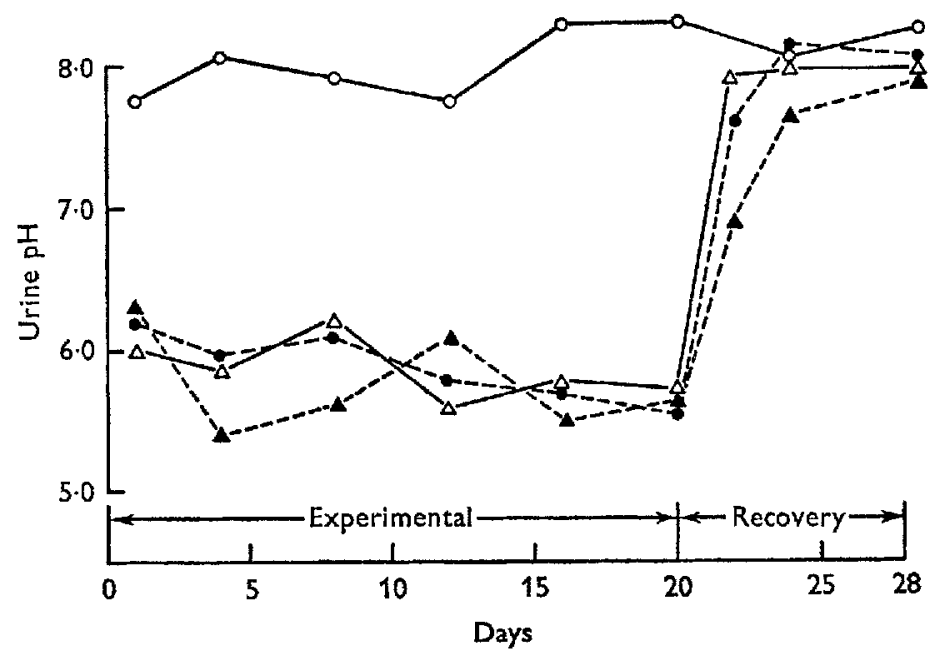

Fig. 4. Mean urine $\mathrm{pH}$ for the four sheep in block $\mathrm{A}$ on the treatments : control $(\mathrm{O}), \mathrm{HCl}(\mathrm{O})$, $\mathrm{HCl}-\mathrm{H}_{2} \mathrm{SO}_{4}(\triangle)$ and $\mathrm{H}_{2} \mathrm{SO}_{4}(\Delta)$. Other details as in Fig. $\mathrm{I}$.

on the $\mathrm{H}_{2} \mathrm{SO}_{4}$ and $\mathrm{HCl}-\mathrm{H}_{2} \mathrm{SO}_{4}$ treatments increased by about $2 \cdot 0$ and $\mathrm{I} \cdot 0 \mathrm{mg} / \mathrm{I} 00 \mathrm{ml}$ respectively from day 2 of treatment, and then remained constant relative to the control values before decreasing to the original values within I $\mathrm{d}$ of the beginning of the recovery period. The concentrations of $\mathrm{Cl}, \mathrm{Ca}, \mathrm{Mg}, \mathrm{K}, \mathrm{Na}$ and inorganic $\mathrm{P}$ in the serum of the sheep were not significantly affected by treatment (Table 4 ).

\section{Urinary $p H$, bicarbonate and ammonia- $N$ excretion}

The pH of the urine (Fig. 4) of the sheep on the control diet remained constant throughout the experiment at around 8.0 . The values on each of the acid treatments decreased to 6.0 within $24 \mathrm{~h}$ and they remained at this or slightly below it throughout the $20 \mathrm{~d}$. When the acid supplements were withdrawn the values returned to normal within $3 \mathrm{~d}$, the increase being more gradual after the $\mathrm{H}_{2} \mathrm{SO}_{4}$ treatment than after the other acid treatments.

On the control diet the excretion of bicarbonate in urine (Fig. 5) was around $\mathrm{I}_{3} \mathrm{O}$ $\mathrm{mmol} / \mathrm{d}$ throughout the experiment. On each acid treatment bicarbonate excretion in urine decreased within $2 \mathrm{~d}$ to about $30 \mathrm{mmol} / \mathrm{d}$ and remained at this value except for days $4^{-8}$ on the $\mathrm{HCl}$ and $\mathrm{HCl}-\mathrm{H}_{2} \mathrm{SO}_{4}$ treatments. During the recovery period bicarbonate excretion increased to the control level within $4 \mathrm{~d}$ except after the $\mathrm{H}_{2} \mathrm{SO}_{4}$ treatment, when the increase was more gradual.

Excretion of ammonia-N in urine (Fig. 5) was constant for the sheep on the control diet at about $25 \mathrm{mmol} / \mathrm{d}$. On each of the acid treatments ammonia- $\mathrm{N}$ excretion increased gradually up to day 6 and then remained relatively constant at 100-I 50 $\mathrm{mmol} / \mathrm{d}$. The rate of increase and the amount excreted on the $\mathrm{H}_{2} \mathrm{SO}_{4}$ treatment was lower than on the $\mathrm{HCl}$ or $\mathrm{HCl}-\mathrm{H}_{2} \mathrm{SO}_{4}$ treatment. During the recovery period after each acid treatment ammonia- $\mathrm{N}$ excretion decreased to the control value within about 4 d. 
Vol. 28
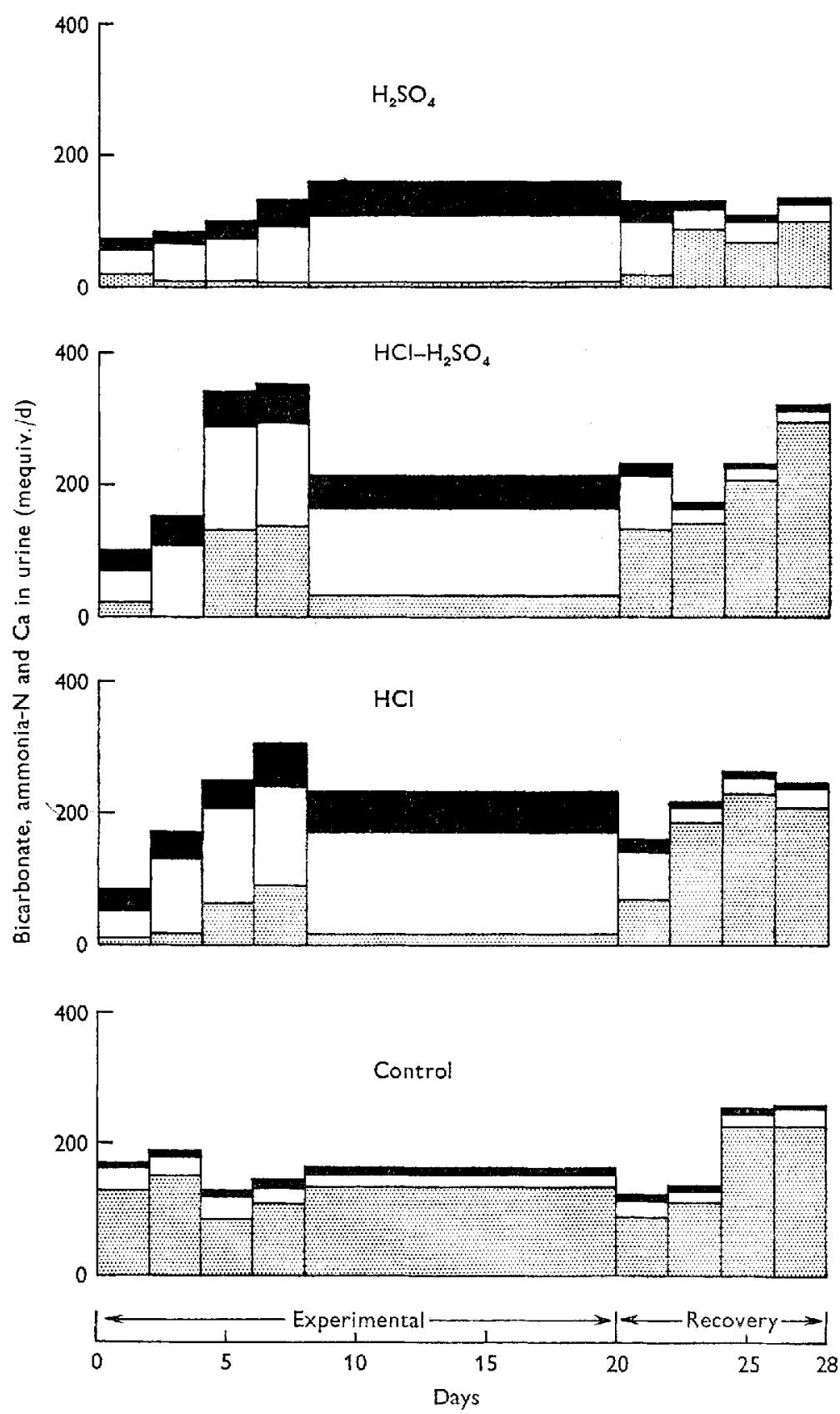

Fig. 5. Mean urinary excretion of bicarbonate (国), ammonia-N ( $\square$ ) and calcium ( $\square$ ) by the four sheep in block A. Other details as in Fig. I.

\section{Intake, excretion and balance of $\mathrm{S}$ and $\mathrm{Cl}$}

During the 8-20 d period, intake of $S$ was increased from the control level of $6.5 \mathrm{~g} / \mathrm{d}$ to 8.04 and $9.89 \mathrm{~g} / \mathrm{d}$ on the $\mathrm{HCl}-\mathrm{H}_{3} \mathrm{SO}_{4}$ and $\mathrm{H}_{2} \mathrm{SO}_{4}$ treatments respectively (Table 5 ). Faecal $\mathrm{S}$ excretion expressed in $\mathrm{g} / \mathrm{d}$ was lower, though not significantly so, on each acid 
Table 5. Intake, faecal and urinary excretion and balance of sulphur and chloride for days 8 to 20 by sheep given grass meal alone or supplemented with mineral acids

\begin{tabular}{|c|c|c|c|c|c|c|}
\hline & \multicolumn{3}{|c|}{ (Means for four sheep/treatment) } & \multirow[b]{2}{*}{$\begin{array}{c}\text { Grass } \\
\text { meal + } \\
\mathrm{H}_{2} \mathrm{SO}_{4}\end{array}$} & \multirow[b]{2}{*}{$\begin{array}{l}\text { SE of } \\
\text { treatment } \\
\text { mean }\end{array}$} & \multirow[b]{2}{*}{$F$ test $\uparrow$} \\
\hline & $\begin{array}{l}\text { Control } \\
\text { (grass } \\
\text { meal } \\
\text { alone) }\end{array}$ & $\begin{array}{c}\text { Grass } \\
\text { meal + } \\
\text { HCl }\end{array}$ & $\begin{array}{c}\text { Grass } \\
\text { meal }+ \\
\left(\mathrm{HCl}-\mathrm{H}_{2} \mathrm{SO}_{4}\right)\end{array}$ & & & \\
\hline \multicolumn{7}{|l|}{ Sulphur: } \\
\hline Intake $(\mathrm{g} / \mathrm{d})$ & $6 \cdot 50$ & $5 \cdot 38$ & 8.04 & $9 \cdot 89$ & - & - \\
\hline Faecal S (g/d) & 3.50 & $2 \cdot 94$ & $2 \cdot 88$ & $2 \cdot 65$ & 0.29 & NS \\
\hline Faecal S (g/roog DM eaten) & 0.25 & 0.26 & 0.26 & 0.26 & 0.01 & NS \\
\hline Faecal $\mathrm{S}$ as $\%$ of intake & $54^{\mathrm{a}}$ & $55^{\mathrm{a}}$ & $3^{6 \mathrm{~b}}$ & $27^{\mathrm{c}}$ & $I \cdot 36$ & ***** \\
\hline Urinary $\mathrm{S}(\mathrm{g} / \mathrm{d})$ & $2 \cdot 81^{a}$ & $2 \cdot 54^{\mathrm{a}}$ & $4 \cdot 54^{\mathrm{b}}$ & $5 \cdot 94^{b}$ & 0.41 & $* *$ \\
\hline Urinary $\mathrm{S}$ as $\%$ of intake & $43^{a}$ & $4^{8^{a}}$ & $56^{\mathrm{b}}$ & $6 \mathrm{Ib}$ & I. 98 & $* *$ \\
\hline Balance $(\mathrm{g} / \mathrm{d})$ & 0.16 & 0.08 & 0.64 & $1 \cdot 32$ & $0.3 x$ & NS \\
\hline \multicolumn{7}{|l|}{ Chloride: } \\
\hline Intake $(\mathrm{g} / \mathrm{d})$ & $17 \cdot 8$ & $29 \cdot 2$ & $20 \cdot 7$ & $12 \cdot 8$ & - & - \\
\hline Faecal $\mathrm{Cl}(\mathrm{g} / \mathrm{d})$ & $I \cdot I$ & 0.8 & 0.7 & $\mathbf{I} \cdot \mathbf{I}$ & 0.20 & NS \\
\hline Faecal Cl (g/Ioo g DM eaten) & 0.077 & 0.064 & 0.064 & 0.073 & 0.018 & NS \\
\hline Faecal $\mathrm{Cl}$ as $\%$ of intake & $6 \cdot 4^{\mathrm{ab}}$ & $2 \cdot 5^{\mathrm{a}}$ & $3 \cdot 4^{\mathrm{a}}$ & $9 \cdot 2^{\mathrm{b}}$ & $I \cdot 28$ & * \\
\hline Urinary $\mathrm{Cl}(\mathrm{g} / \mathrm{d})$ & $13 \cdot 8^{\mathrm{ac}}$ & $24 \cdot 2^{b}$ & I $6 \cdot 2^{\mathrm{c}}$ & $9 \cdot 6^{\mathrm{a}}$ & $I \cdot 67$ & $* *$ \\
\hline Urinary $\mathrm{Cl}$ as $\%$ of intake & 78 & 83 & 80 & 75 & 3.94 & NS \\
\hline Balance $(g / d)$ & $2 \cdot 9$ & $4 \cdot 2$ & $3 \cdot 6$ & $2 \cdot 2$ & $0: 36$ & NS \\
\hline
\end{tabular}

$\uparrow$ Where the $F$ test shows a significant treatment effect the means are significantly different from each other $(P<0.05)$ if they do not have a letter in common. NS, $P>0.05 ; * 0.05>P>0.01 ; * * 0.01>$ $P>0.001$; *** $P<0.001$.

treatment than on the control treatment; expressed in g/I $00 \mathrm{~g}$ DM eaten, it was the same on all four treatments. Faecal $\mathrm{S}$ expressed as a percentage of $\mathrm{S}$ intake was significantly lower on the $\mathrm{HCl}-\mathrm{H}_{2} \mathrm{SO}_{4}$ and $\mathrm{H}_{2} \mathrm{SO}_{4}$ treatments than on the control and $\mathrm{HCl}$ treatments. Urinary $\mathrm{S}$ excretion expressed in $\mathrm{g} / \mathrm{d}$ and as a percentage of intake was significantly higher $\left(P<\mathrm{O}^{\circ} \mathrm{OI}\right)$ on the $\mathrm{HCl}-\mathrm{H}_{2} \mathrm{SO}_{4}$ and the $\mathrm{H}_{2} \mathrm{SO}_{4}$ treatments. There was no significant treatment effect on the balance of $\mathrm{S}$ though it was highest on the $\mathrm{HCl}-\mathrm{H}_{2} \mathrm{SO}_{4}$ and the $\mathrm{H}_{2} \mathrm{SO}_{4}$ treatments.

The excretion of $\mathrm{S}$ in faeces on the $\mathrm{H}_{2} \mathrm{SO}_{4}$ treatments was highest for the first $2 \mathrm{~d}$ of treatment and then decreased to a constant level (Fig. 6a), indicating that the absorption of the supplementary sulphate was lowest immediately after the introduction of the treatment. Urinary $\mathrm{S}$ excretion on the $\mathrm{H}_{2} \mathrm{SO}_{4}$ treatment was as high for the first $2 \mathrm{~d}$ of treatment as subsequently and it quickly decreased during the recovery period, indicating that the supplementary sulphate was rapidly absorbed and excreted in the urine. This pattern of $\mathrm{S}$ excretion was not so clear on the $\mathrm{HCl}-\mathrm{H}_{2} \mathrm{SO}_{4}$ treatment, where of course the increase in $\mathrm{S}$ intake was not so great.

$\mathrm{Cl}$ intake increased from the control level of 17.8 to 29.2 and $20.7 \mathrm{~g} / \mathrm{d}$ on the $\mathrm{HCl}$ and $\mathrm{HCl}-\mathrm{H}_{2} \mathrm{SO}_{4}$ treatments respectively for days 8-20 (Table 5). Faecal excretion of $\mathrm{Cl}$, expressed in $\mathrm{g} / \mathrm{d}$ or in $\mathrm{g} / \mathrm{1} / 00 \mathrm{~g}$ DM caten, was not affected by treatment but was significantly decreased by the $\mathrm{HCl}$ treatment when expressed as a percentage of $\mathrm{Cl}$ intake (Fig. 6b). The $\mathrm{HCl}$ and the $\mathrm{HCl}-\mathrm{H}_{2} \mathrm{SO}_{4}$ treatments significantly increased urinary $\mathrm{Cl}$ excretion when expressed in $\mathrm{g} / \mathrm{d}$, but not when expressed as a percentage of $\mathrm{Cl}$ intake. There was no significant treatment effect on the balance of $\mathrm{Cl}$. On the $\mathrm{HCl}$ and $\mathrm{HCl}-\mathrm{H}_{2} \mathrm{SO}_{4}$ treatments urinary $\mathrm{Cl}$ excretion was almost as high on the first $2 \mathrm{~d}$ 
(a)

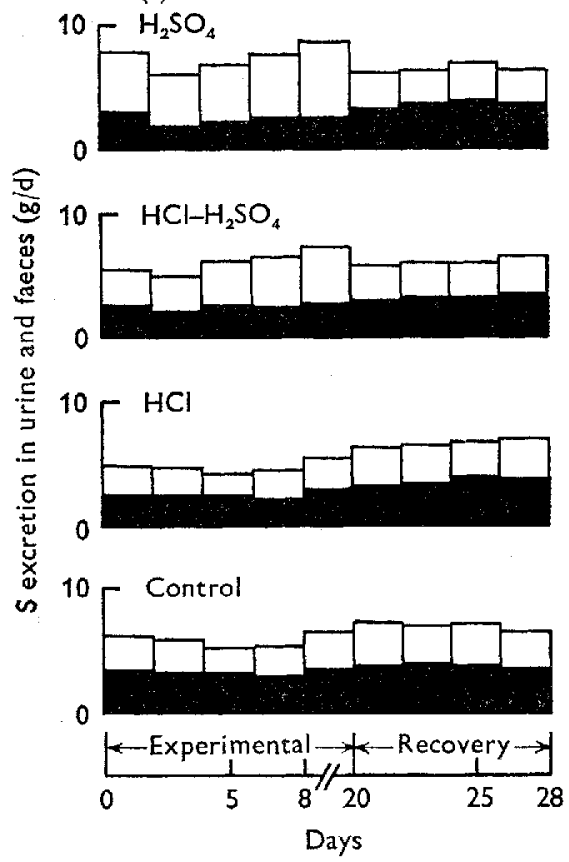

(b)

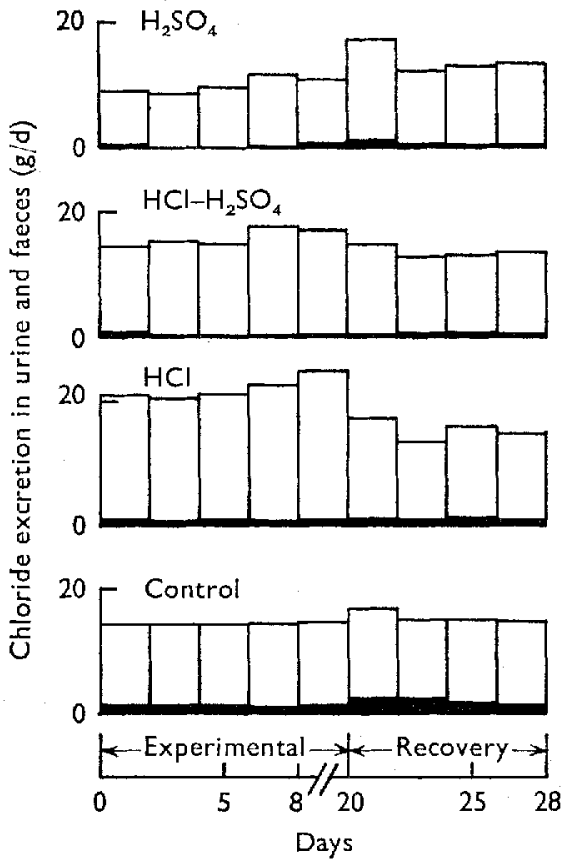

Fig. 6. Pattern of excretion throughout the experiment of $(a)$ sulphur and $(b)$ chloride in faeces (D) and in urine ( $\square$ ) by the four sheep/treatment in block A. Other details as in Fig. I.

of treatment as subsequently and the values decreased to the control levels within $2 \mathrm{~d}$ of the recovery period. Faecal $\mathrm{Cl}$ showed no increase after introduction of the acid treatments.

Intake, excretion and balance of $\mathrm{Ca}, \mathrm{P}, \mathrm{Mg}, \mathrm{K}$ and $\mathrm{Na}$

Urinary $\mathrm{Ca}$ excretion was increased to ten times its value by each acid treatment (Table 6), the output increasing gradually during the first $8 \mathrm{~d}$ after introduction of the acids (Fig. 5). During the recovery period urinary $\mathrm{Ca}$ excretion decreased rapidly to the control values within $4 \mathrm{~d}$. Faecal $\mathrm{Ca}$ excretion was not affected by treatment and consequently the balance of $\mathrm{Ca}$ was negative on each acid treatment at about $0.5 \mathrm{~g} / \mathrm{d}$ compared with a positive balance of $0.6 \mathrm{~g} / \mathrm{d}$ on the control (Table 6).

The percentage of dietary $\mathrm{P}$ excreted in faeces was significantly increased by each acid treatment compared with the control (Table 6). Urinary $\mathrm{P}$ excretion was not affected by treatment. The balances of $P$ on each acid treatment were the same at approximately $0.05 \mathrm{~g} / \mathrm{d}$, which was significantly lower than the balance on the control at $0.49 \mathrm{~g} / \mathrm{d}$.

Mg excretion in urine expressed as a percentage of intake was significantly higher on each acid treatment than on the control but faecal excretion and balance of $\mathrm{Mg}$ were not affected by treatment (Table 6). There was no significant treatment effect on urinary or faecal excretion or balance of $\mathrm{K}$ (Table 6).

The percentage of dietary $\mathrm{Na}$ excreted in faeces was lower on each acid treatment than on the control treatment, though the difference was not significant (Table 6). 
Table 6. Intake, faecal and urinary excretion and balance of calcium, phosphorus, magnesium, potassium and sodium for days 8-20 by sheep given grass meal alone or supplemented with mineral acids

Calcium

Intake $(\mathrm{g} / \mathrm{d})$

Faecal $\mathrm{Ca}$ as $\%$ of intake

Urinary $\mathrm{Ca}$ as $\%$ of intake

Balance ( $g / d$ )

Phosphorus

Intake $(\mathrm{g} / \mathrm{d})$

Faecal $\mathrm{P}$ as $\%$ of intake

Urinary $\mathrm{P}$ as $\%$ of intake

Balance $(\mathrm{g} / \mathrm{d})$

Magnesium

Intake $(\mathrm{g} / \mathrm{d})$

Faecal $\mathrm{Mg}$ as $\%$ of intake

Urinary $\mathrm{Mg}$ as \% of intake

Balance ( $g / d$ )

(Means for four sheep/treatment)

Control

(grass

meal

alone)

Grass

meal +

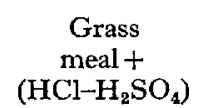

Grass

SE of
treatment

$\mathrm{HCl}$

$\left(\mathrm{HCl}-\mathrm{H}_{2} \mathrm{SO}_{4}\right)$

mealt

mean $F$ test $\dagger$

$\begin{array}{lc}10.33 & 8.60 \\ 94 & 93 \\ 0.93^{\mathrm{a}} & 13.4^{\mathrm{b}} \\ 0.60^{\mathrm{a}} & -0.65^{\mathrm{b}}\end{array}$

$8 \cdot 05$
95
$1 \mathrm{I} \cdot 7^{\mathrm{b}}$
$-0.44^{\mathrm{b}}$

$2 \cdot 90$
$96^{\mathrm{b}}$
$\mathrm{I} \cdot 65$
$0.07^{\mathrm{b}}$

$7 \cdot 37$

92

$\mathrm{r}_{3} \cdot \mathrm{ob}^{\mathrm{b}}$

$-0.34^{b}$

2.00

0.70

NS

$3 \cdot 7 x$

$86^{\mathrm{a}}$

$3 \cdot 07$
$96^{\mathrm{b}}$
$3 \cdot 44$

$\begin{array}{ll}\mathrm{I} \cdot 3^{\mathrm{I}} & 3.44 \\ 0.49^{\mathrm{a}} & 0.02^{\mathrm{b}}\end{array}$

$0.07^{\mathrm{b}}$

$2 \cdot 64$
$96^{\mathrm{b}}$
$2 \cdot 20$
$0 \cdot 06^{\mathrm{b}}$

0.22

****

$\begin{array}{cc}2 \cdot 82 & 2 \cdot 33 \\ 86 & 87 \\ 14 \cdot 2^{a} & 17 \cdot 6^{b} \\ -0.02 & -0.10\end{array}$

$2 \cdot 22$

86

$17 \cdot 2^{b}$

$-0.03$

88

88
$18 \cdot 4$

$-0.14$

$\begin{array}{cc}- & - \\ \mathbf{I} \cdot 76 & * \\ 0.64 & N S \\ 0.06 & * *\end{array}$

Potassium

Intake (g/d)

Faecal $\mathrm{K}$ as $\%$ of intake

Urinary $\mathrm{K}$ as $\%$ of intake

Balance (g/d)

$\begin{array}{cc}35 \cdot 3 & 29 \cdot 3 \\ 7 \cdot 4 & 7 \cdot 9 \\ 83 & 86 \\ 3 \cdot 6 & 1 \cdot 7 \\ & \\ 3 \cdot 80 & 3 \cdot 12 \\ 49 & 21 \\ 37^{\mathrm{a}} & 75^{\mathrm{c}} \\ 0.45 & 0.3 \mathrm{I}\end{array}$

$27 \cdot 4$
$7 \cdot 4$
86
$2 \cdot 2$
$2 \cdot 98$
25
$59^{b c}$
$0 \cdot 33$

$25^{\circ}$

9.1

83

$1 \cdot 9$

$\begin{array}{lc}- & \text { NS } \\ 2.5 & \text { * } \\ 0.79 & \text { NS } \\ 0.06 & \end{array}$

Sodium

Intake $(\mathrm{g} / \mathrm{d})$ Faecal $\mathrm{Na}$ as $\%$ of intake

Urinary $\mathrm{Na}$ as \% of intake

Balance $(g / d)$

† Where the $F$ test shows a significant treatment effect the means are significantly different from each other $(P<0.05)$ if they do not have a letter in common. NS, $P>0.05 ; 0.05>P>0.01 ; * 0.01>$ $P>0.001 ; * * * P<0.001$.

However, the percentage of dietary $\mathrm{Na}$ excreted in urine was significantly higher on two acid treatments than on the control $(P<0.05)$. There was no significant treatment effect on the balance of $\mathrm{Na}$. Thus, the acid treatments changed the excretory pattern of $\mathrm{Na}$ by decreasing faccal output and increasing urinary output. The increase in urinary $\mathrm{Na}$ excretion was greatest during the first $4 \mathrm{~d}$ of treatment, the decrease in faecal output was greatest from days 2 to 8 , but both values returned to the control values within $2 \mathrm{~d}$ of the beginning of the recovery period.

\section{Intake of acid and excretion of electrolytes in urine}

The intakes of mineral acid calculated from the amount added and from the $\mathrm{Cl}$ and $\mathrm{S}$ contents of the food residue were 397,333 and 299 mequiv./d on the $\mathrm{HCl}$, $\mathrm{HCl}-\mathrm{H}_{2} \mathrm{SO}_{4}$ and $\mathrm{H}_{2} \mathrm{SO}_{4}$ treatments respectively, for days $0-20$. Although DM intakes were the same on the $\mathrm{HCl}$ and $\mathrm{HCl}-\mathrm{H}_{2} \mathrm{SO}_{4}$ treatments, the amount of acid left in the food residue, as indicated by $\mathrm{Cl}$ and $\mathrm{S}$ contents, was greater on the $\mathrm{HCl}-\mathrm{H}_{2} \mathrm{SO}_{4}$ than on the $\mathrm{HCl}$ treatment. It should be noted that the food residues were dried before 
Table 7. Intake of acid and the excretion of electrolytes in urine for days 8-20 by sheep given grass meal alone or supplemented with mineral acids

(Means for four sheep/treatment)

Acid intake (mequiv./d)

Electrolytes in urine (mequiv./d)

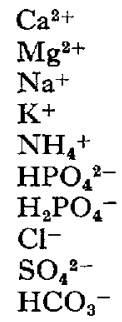

$\begin{array}{cc}\begin{array}{c}\text { Control } \\ \text { (grass }\end{array} & \text { Grass } \\ \text { meal } & \text { meal+ } \\ \text { alone) } & \mathrm{HCl} \\ 0 & 414 \\ 5 & 59 \\ 33 & 34 \\ 63 & 94 \\ 745 & 645 \\ 20 & 159 \\ 3 \cdot 0 & \mathrm{I} \cdot 2 \\ 0.1 & 2 \cdot 9 \\ 384 & 682 \\ 192 & 158 \\ 137 & 17\end{array}$

$\begin{array}{cc}\text { Grass } & \text { Grass } \\ \text { meal }+ & \text { meal + } \\ \left(\mathrm{HCl}-\mathrm{H}_{2} \mathrm{SO}_{4}\right) & \mathrm{H}_{2} \mathrm{SO}_{4} \\ 352 & 319 \\ 49 & 48 \\ 33 & 31 \\ 79 & 62 \\ 592 & 538 \\ 127 & 105 \\ 0 \cdot 4 & 0 \cdot 6 \\ \mathrm{I} \cdot 3 & 1 \cdot 6 \\ 457 & 274 \\ 283 & 370 \\ 39 & 6\end{array}$

analysis, which may have resulted in some loss of free $\mathrm{HCl}$ by volatilization. The treatment effects on electrolyte excretion in urine have already been presented, but the values for each electrolyte expressed in mequiv./d are compared with acid intake for days $8-20$ in Table 7 . It is clear that, apart from $\mathrm{Cl}$ and sulphate excretion, the major changes caused by the acid treatments were on $\mathrm{Ca}$, ammonia- $\mathrm{N}$ and bicarbonate excretion. The effect on $\mathrm{K}$, which was the predominant electrolyte in urine, was due to decreased food and consequently decreased $\mathrm{K}$ intake.

\section{DISCUSSION}

The $19 \%$ reduction in voluntary intake of the pelleted grass meal caused by the $\mathrm{HCl}$ treatment can be ascribed to excess acid rather than $\mathrm{Cl}$ intake, since much higher levels of dietary $\mathrm{Cl}$ as $\mathrm{NaCl}$ had little effect on voluntary food intake of sheep (Meyer \& Weir, 1954; Pierce, 1957; Upton, 1970). The cause of this reduced intake could be related to several factors known to affect voluntary food intake of ruminants, such as rumen $\mathrm{pH}$, rumen acetate concentration, DM digestibility, prolonged food retention, palatability and metabolic disturbance.

Bhattacharya \& Warner (Ig67) observed that direct infusion of lactic, citric or phosphoric acid into the rumen of steers to maintain the $\mathrm{pH}$ of rumen fluid at 6.0 or 0.6 units below normal control values caused a 50-70\% reduction in food intake, which they ascribed to the lower rumen fluid $\mathrm{pH}$. In our experiment the $\mathrm{HCl}$ treatment reduced rumen fluid $\mathrm{pH}$ of the sheep by less than 0.2 units which would seem to rule out this factor as the main cause of the reduction in food intake. Furthermore, the $\mathrm{HCl}$ treatment had little or no effect on total or individual VFA concentrations in rumen fluid, which rules out high acetate concentration, shown by Baile (I968) to affect food intake, as a possible cause. Likewise om digestibility is ruled out, as it was, in fact, slightly increased by the $\mathrm{HCl}$ treatment. It is possible that the increase in DM digestibility resulted from prolonged food retention in the rumen due to an effect of the $\mathrm{HCl}$ treatment on rumen motility. It is more likely, however, that the increase in DM 
digestibility of the grass pellets was caused by the lower DM intake as shown by Wainman, Smith \& Blaxter (x 97 I).

Reduced palatability due to the low $\mathrm{pH}(3.8)$ of the diet could be a factor, particularly in view of the recent report of McLeod, Williams \& Raymond (1970) that increasing the $\mathrm{pH}$ of silage (made without mineral acids) with $\mathrm{NaHCO}_{3}$ increased the intake of the silage by sheep and cattle. In our experiment DM intake was reduced only slightly on the Ist day of treatment (Fig. I), which indicates that palatability was not a major factor involved.

Consequently, it appears that the effect of the $\mathrm{HCl}$ was a metabolic one and was closely related to its effect on the acid-base status of the animals. The $\mathrm{HCl}$ treatment induced a chronic degree of metabolic acidosis which developed rapidly, persisted throughout the $20 \mathrm{~d}$ feeding period and was quickly rectified during the recovery period. The effects of acid intake on metabolic acidosis noted here are comparable with observations on acid loading in cattle (Lebeda, Bouda \& Kučera, 1970) and less severe than those observed in goats (Fencl, Miller \& Pappenheimer, I966). As the acidosis developed, food intake decreased, likewise when it was rectified during the recovery period food intake returned to normal (Figs $\mathrm{I}, 4$ ).

The extra reduction in food intake caused by the $\mathrm{H}_{2} \mathrm{SO}_{4}$ treatment is ascribed to the high content of dietary sulphate-S $\left(0.5^{6} \mathrm{~g} / \mathrm{I00} \mathrm{g} \mathrm{DM}\right)$ contributed by this treatment, whereas the content contributed by the $\mathrm{HCl}-\mathrm{H}_{2} \mathrm{SO}_{4}$ treatment $(0.28 \mathrm{~g} / \mathrm{IOO} \mathrm{g}$ DM) was too low to have any effect. This extra effect cannot be ascribed to changes in rumen fluid $\mathrm{pH}$ or VFA concentrations or DM digestibility as these were the same as on the $\mathrm{HCl}$ treatment. Palatability also appears to be ruled out as intake was reduced only slightly on the ist day of treatment (Fig. I). The degree of metabolic acidosis induced by the $\mathrm{H}_{2} \mathrm{SO}_{4}$ treatment was somewhat less than that induced by the other acid treatments and accordingly can be discounted as contributing to the extra reduction in food intake. Excess dietary sulphate-S as sodium sulphate has previously been shown to affect food intake of sheep adversely (L'Estrange et al. 1969; Upton, 1970). Weeth \& Hunter (I97I) have shown recently that high levels of sulphate in drinking-water reduced voluntary food intake of cattle.

The reduction in food intake on the $\mathrm{H}_{2} \mathrm{SO}_{4}$ treatment was less than would be expected from the report of Virtanen (1933), who observed with cows that silage preserved with $\mathrm{H}_{2} \mathrm{SO}_{4}$ alone was associated with extremely low intakes compared with silage preserved with a I : I mixture of $\mathrm{HCl}$ and $\mathrm{H}_{2} \mathrm{SO}_{4}$. The results here are, however, similar to those of a previous experiment on sheep (L'Estrange et al. 1969) in which ammonium bisulphate, ammonium sulphate or sulphuric acid, added to a grass-meal diet to provide $\mathrm{I} \% \mathrm{~S}$ in the food DM, each caused a reduction of approximately $44 \%$ in DM intake. They also agree with the effect of adding ammonium bisulphate to silage on voluntary intake by cattle (McCarrick, Maguire, Poole \& Spillane, 1965).

The effects of the mineral acids on mineral metabolism were closely related. The major effect was an increase in urinary $\mathrm{Ca}$ excretion. There was also an increase in urinary $\mathrm{Na}$ and $\mathrm{Mg}$ excretion, a decrease in faecal $\mathrm{Na}$ excietion and an increase in faecal $\mathrm{P}$ excretion. The mineral acids adversely affected the balance of $\mathrm{Ca}$ and $\mathrm{P}$ but were without effect on the excretion or balancc of $\mathrm{K}$. These results are similar to those 
previously reported for sheep given ammonium bisulphate, ammonium sulphate and sulphuric acid (L'Estrange, 1970 ).

The metabolisms of the supplementary $\mathrm{S}$ and of the supplementary $\mathrm{Cl}$ were similar in many respects, both elements being almost entirely absorbed and excreted in the urine. The only major difference noted between them was that the supplementary $\mathrm{S}$ increased serum sulphate-S concentration, whereas the supplementary Cl had no effect on serum $\mathrm{Cl}$ concentration, possibly because $\mathrm{Cl}$ has a much greater volume of distribution in the body than sulphate (Wolf \& McDowell, 1954). The different distribution within body fluids may partly explain why voluntary food intake is more sensitive to sulphate than to chloride in the dict.

We are indebted to Professor D. M. McAleese for helpful advice and criticism and to Dr D. Kellegher for advice on statistical analysis. We thank Mr S. Dillon, Miss K. McCormack and Miss A. McGuigan for their skilled technical assistance.

\section{REFERENCES}

Association of Official Agricultural Chemists (1965). Official Methods of Analysis roth ed. Washington DC: Association of Official Agricultural Chemists.

Baile, C. A. (1968), Fedn Proc. Fedn Am. Socs exp. Biol. 27, 1361.

Baumgardt, B. R. (1964). Bull. Wis. Univ. Dep. Dairy Sci. no. I.

Bhattacharya, A. N. \& Warner, R. G. (I967). F. Dairy Sci. 50, iा I6.

Billitzer, A. W. \& Jarrett, I. G. (1970). Aust. F. biol. Sci. 23, 9 I 5.

Blaxter, K. L. \& Wilson, R. S. (r962). Anim. Prod. 4, 35 I.

Bryan, W. B. (1964). Consumption and physiological effects in the dairy cow of grass silage with different additives. MAgrSc Thesis, National University of Ireland.

Clifford, A. J. ( $(963)$. Comparative studies on the physiological effects of feeding grass silage with different additives on dairy cows. MAgrSc Thesis, National University of Ireland.

Conway, E. J. (1962). Microdiffusion Analysis and Volumetric Error 5 th revised ed. London: Crosby Lockwood.

Davenport, H. W. (1969). The ABC of Acid-Base Chemistry 5th ed. Chicago and London: University of Chicago Press.

Dean, G. A. (1966). Analyst, Lond. 91, 530.

Fencl, V., Miller, 1. B. \& Pappenheimer, J. R. (1966). Am. F. Physiol. 210, 459 .

Fiske, C. H. \& Subbarow, Y. (1925). J. biol. Chem. 66, 375 .

Lebeda, M., Bouda, J. \& Kučera, A. (1970). Acta vet. Brno. 39, 415.

L'Estrange, J. L. (1970). Ir. \%. agric. Res. 9, I6I.

L'Estrange, J. L., Clarke, J. J. \& McAlcese, D. M. (r969). Ir. F. agric. Res. 8, 133.

L'Estrange, J. L. \& Murphy, F. (1971). Proc. Nutr. Soc. 30, 21 A.

McCarrick, R. B. (1962). Ir. F. agric. Res. 1, 267.

McCarrick, R. B. (1964). Ir. F. agric. Res. 3, 99 .

McCarrick, R. B., Keane, E. \& Tobin, J. (1965). Ir. F. agric. Res, 4, I I5.

McCarrick, R. B., Maguire, M. F., Poole, D. B. R. \& Spillane, T. (1965). Ir. F. agric. Res. 4, 135.

McCarrick, R. B., Poole, D. B. R. \& Maguire, M. F. (1965). Ir. F. agric. Res. 4, 125.

McLeod, D. S., Williams, R. J. \& Raymond, W. F. (1970). F. agric. Sci., Camb. 75, 311.

Meyer, J. H. \& Weir, W. C. (1954). F. Anim. Sci. 13, 443.

Pierce, A. W. (1957). Aust. F. agric. Res. 8, $7 \mathrm{I}$.

Shaw, W. M. (1959). F. agric. Fd Chem. 7, 843 .

Upton, P. K. (1970). Some biological and chemical aspects of sulphut metabolism in the ruminant. PhD Thesis, National University of Ireland.

Virtanen, A. J. (1933). Emp. F. exp. Agric. x, I43.

Wainman, F. W., Smith, J. S. \& Blaxter, K. L. (г97I), Proc. Nutr. Soc. 3o, 23 A.

Weeth, H. J. \& Hunter, J. E. (1971). J. Anim. Sci. 32, 277.

Wolf, A. V. \& McDowell, M. E. (1954). Am. F. Physiol. r76, 207. 